\title{
PENGUATAN PERAN DAKWAH MAJELIS TA'LIM AN-NUR DESA ROMPO KECEMATAN LANGGUDU KABUPATEN BIMA
}

\author{
Irwan ${ }^{*}$, Ade Rahman' ${ }^{2}$, Syarif Hidayatullah ${ }^{3}$, Mei Indra Jayanti ${ }^{4}$ \\ Institut Agama Islam (IAI) Muhammadiyah Bima ${ }^{1,2,3}$, STKIP Bima ${ }^{4}$, Indonesia
}

Corresponding Author: Irwan, rirwantalabiu@gmail.com

\section{ABSTRAK}

Majelis ta'lim sebagai lembaga lembaga pendidikan non formal berkembang pesat di indonesia. Baik di kota-kota besar maupun di desa pasti terdapat mejelis taklim yang kebanyakan didominasi perempuan terutama kaum ibu. Belakangan banyak ibu-ibu yang mengikuti pengajian menggunakan seragam yang sama dan menunjukan ciri khas majlis taklimnya masing-masing. Majelis taklim bukan hanya bergerak dalm bidang keagamaan

ARTICLE INFO

Article history:

Received

9 Januari 2022

Revised

14 Januari 2022

Accepted

19 Januari 2022

saja melainkan juga dibidang sosial dan budaya. Tujuan dari pelaksanaan kegiatan pengabdian masyarakat sebagai suatu proses penguatan peranan para ibu-ibu majelis ta'lim dalam melakukan dakwah Islam yang berbasis pada gerakan amar ma'ruf nahi munkar terhadap generasi perempuan terutama para remaja putri dalam kehidupan sosial masyarakat khusus di Desa Rompo Kecamatan Langgudu Kabupaten Bima. Kegiatan pengabdian masyarakat dilakukan pada saat pendampingan kegiatan KKN-PAR melalui pelaksanaan seminar dan FGD bersama pengurus majelis ta'lim An-Nur Desa Rompo Kecematan Langgudu. Pengabdian inipun berorientasi pada penguatan pemahaman Islam dan strategi dakwah bagai para ibu-ibu majelis Ta'lim An-Nur Desa Romo Kecamatan Langgudu, sehinggga diharapkan mampu mengambil peranan dalam pengembangan kehidupan Islami bagi para kaum perempuan khusnya Desa Rompo Kecamatan Langgudu Kabupaten Bima.

Kata Kunci: Majelis Ta'lim, Peran Dakwah Islam, An-Nur

How to Cite : Irwan, Ade Rahman, Syarif Hidayatullah, Jayanti, Mei Indra. (2022). Penguatan Peran Dakwah Majelis Ta'lim An-Nur Desa Rompo Kecematan Langgudu Kabupaten Bima. Taroa: Jurnal Pengabdian Masyarakat, 1(1), 52-59.

DOI : https://doi.org/https://doi.org/10.52266/

Journal Homepage: https://ejournal.iaimbima.ac.id/index.php/

This is an open access article under the CC BY SA license

: https://creativecommons.org/licenses/by-sa/4.0/

\section{PENDAHULUAN}

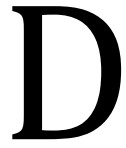

esa merupakan suatu wilayah yang di tempati sejumlah penduduk sebagai kesatuan masyarakat yang di dalamnya terdapat kesatuan hukum yang memiliki organisasi pemerintah terrendah langsung di bawah camat dan tidak berhak menyelengarakan rumah tangga sendiri. Desa Rompo merupakan salah satu desa dari 15 (lima belas) desa yang ada di bagian barat kecematan langgudu dengnan luas wilayah 8.79 H. Dengan jumlah penduduk 2.070 jiwa yang terdiri dari Laki -laki sebanyank 1.024 orang, permpuan sebanyak 1.045 orang dan memiliki kepala keluarga sebanyak 592 KK dengan 
batas batas wilayah: Sebelah utara: desa waworada kecematan langgudu,Sebelah selatan: teluk waworada, Sebelah barat: tambak desa waworada dan Sebelah timur: desa karumbu kecematan langgudu dan Desa Rompo berada di tengah-tengah.Kehidupan sosial masyarakat di Desa Rompo sudah bercampur baur, baik tradisional maupun modern, desa maupun kota, kaya maupun miskin, hampir tidak ada perbedaan.(Arship, 2015)

Saat ini di Desa Rompo terdapat berbagai macam etnis penduduk dari seluruh wilayah yang tinggal di Desa Rompo, walaupun penduduk asli masih berada pada komposisi teratas dan mendominasi dalam berbagai peran kemasyarakata untuk memenuhi kebutuhan sehari-hari masyarakat Desa Rompo pada umumny memiliki mata pencaharian sebagai nelayan yang lebih terarah pada bidang nelayan dan berternak .Keseharian masyarakat Desa Rompo adalah nelayan (jala kuru/porsesaeli pukat dan mancing),bertanih rumput laut, buruh ikan dan berternak kambing, sapi, ayam dan lainlain. Mengingat keberadaan desa rompo yang memiliki area laut yang cukup luas. Perkembangan yang lebih jauh, muncul pergeseran peranan dan fungsi pendidikan dalam masyarakat, tugas prantara dan lembaga pendidikan dan bentuk organisasional pendidikan serta keberadaan modal manusia dalam pendidikan. Hal tersebut menimbulkan konsekuensi tantangan, tuntutan dan kebutuhan baru dalam sendi-sendi pendidikan termasuk sendi-sendi pendidikan di desa Rompo. Kepedulian masyarakat terhadap pendidikan khususnya keluarga sangatlah menentukan keberhasilan pendidikan. Untuk mencapai keberhasilan tersebut, maka sejak dini perlu ditanamkan disiplin belajar kepada generasi muda dan selalu diberikan upaya untuk mengingatkan budaya membaca buku dan Al-quran dan belajar bagi generasi muda dan warga masyarakat Desa Rompo Kecamatan Langgudu Kabupten Bima (Tim KKN-PAR, 2020).

\section{TINJAUAN TEORITIS}

\section{Pengertian Majales Ta'lim}

Eksistensi majelis Ta'lim sebagai wadah Gerakan dakwah dalam pengembangan kegiatan keagamaan di Indonesi tela menjadi nadir Gerakan dakwah Islam bagai kaum perempuan terlebih lagi para Ibu-Ibu di lingkup Desa dan kelurahan pada setiap daerah Kabupaten dan Kota termasuk di Bima NTB. Secara umum, orang cenderung memaknai majelis ta'lim sebagai perkumpulan semi organisasi non formal yang bergerak dalam bidang kajian keagamaan bagi para perempaun yang terdapat ditingkat desa dan kelurahan, serta lebih spesifiknya majalis ta'lim jufa dapat berada di masing RT/RW seitan Desa/Kelurahan. Hal ini sangat bergantung pada adanya keinginan sekolah masyarakat khusunya para Ibu-Ibu atau perempuan yang ingin membentuknya. Pemaknaan terhadap kedudukan majelis ta'lim juga dapat dilihat dari arti etimologisnya bahwas majelis Ta'lim berasal dari bahasa arab yaitu "majlis" (ism) yang berasal dari akar kata jalasa yajlisu julusan (جلس - يجلس - جلوس) yang artinya tempat duduk atau tempat rapat. Untuk kata taklim (ta'lim) merupakan ism masdar dari kata 'alima ya'lamu, ilman ( عَلِمَ يَعْلَمُ - عِلْماً ) yang memiliki arti mengetahui sesuatu, ilmu, dan arti dari ta'lim adalah pengajaran, melatih. Yang kemudian kata ta'lim dibakukan penulisannya dalam bahasa Indonesia menjadi taklim. Sehingga kata majelis ta'lim adalah suatu tempat (wadah) yang didalamnya terdapat proses belajar mengajar para jamaah dan anggota (Marzuki, 2016). Adapun 
Secara terminology majelis ta'alim adalah suatu tempat yang digunakan untuk proses belajar mengajar tentang keislaman dan materi lainnya guna mencapai tujuan-tujuan yang telah ditetapkan. Dari pengertian ini maka komponen majelis taklim menekankan beberapa hal yang dapat dipahami antara lain; 1) Tempat yang digunakan untuk proses belajar mengajar, 2) Materi adalah tentang keislaman atau lainnya, dan 3) Gunanya untuk mencapai tujuan tujuan yang ditetapkan.(Ibnu Singorejo, 2020).

\section{Fungsi Dan Tujuan Terbentukanya Majelis Ta'lim}

Merujuk pada penjelasan beberbagai literatur, turut dikemukakan sejumlah fungsi dan tujuan dari terbentuknya majelis ta'lim dikalngan kominitas para perempuan di desa maupun di daerah perkotaan antara lain sebagai berikut:

1) Majelis Ta'lim dapat berfungsi sebagai tempat kegiatan belajar mengajar umat Islam, khususnya bagi kaum perempuan dalam rangka meningkatkan pengetahuan, pemahaman, dan pengalaman ajaran Islam.

2) Lembaga Pendidikan dan Keterampilan Majelis taklim juga berfungsi sebagai lembaga pendidikan bagi kaum perempuan dalam masyarakat yang berhubungan, antara lain dengan masalah pengembangan kepribadian serta pembinaan keluarga dan rumah tangga sakinah mawaddah warohmah. Melalui Majelis taklim inilah, diharapkan mereka menjaga kemuliaan dan kehormatan keluarga dan rumah tangganya.

3) Wadah Berkegiatan dan Berkreativitas Majelis taklim juga berfungsi sebagai wadah berkegiatan dan berkreativitas bagi kaum perempuan. Antara lain dalam berorganisasi, bermasyarakat, berbangsa dan bernegara. Negara dan bangsa kita sangat membutuhkan kehadiran perempuan yang sholihah dengan keahlian dan keterampilan sehingga dengan kesalehan dan kemampuan tersebut dia dapat membimbing dan mengarahkan masyarakat ke arah yang baik.

4) Pusat Pembinaan dan Pengembangan Majelis taklim juga berfungsi sebagai pusat pembinaan dan pengembangan kemampuan dan kualitas sumber daya manusia kaum perempuan dalam berbagai bidang seperti dakwah, pendidikan sosial, dan politik yang sesuai dengan kodratnya.

5) Jaringan Komunikasi, Ukhuwah dan Silaturahim Majelis taklim juga diharapkan menjadi jaringan komunikasi, ukhuwah, dan silaturahim antar sesama kaum perempuan dalam membangun tatanan kehidupan yang Islami (Hidayah, 2017)

Adapun tujuan dibentukan kelomok majelis Ta'lim mencakup capian beberapa hal di antaranya sebagai berikut:

1) Meningkatkan Kemampuan dan ketrampilan dalam membaca dan memahami alQur'an;

2) Membentuk manusia yang beriman, bertakwa, dan berakhlak mulia;

3) Membentuk manusia yang memiliki pengetahuan agama yang mendalam dan komprehensif;

4) Mewujudkan kehidupan beragama yang toleran dan humanis; dan

5) Memperkokoh nasionalisme, kesatuan dan ketahanan bangsa (Ibnu Singorejo, 2020).

\section{METODE PENGABDIAN}

Kegiatan pengabdian masyarakat ini dalam bentuk Penguatan Peran Dakwah Majelis Ta'lim An-Nur Desa Rompo Kecematan Langgudu Kabupaten Bima yang dilaksanaakan selama kegiatan KKN-PAR Mahasiswa IAI Muhammadiyah Bima Tahun 2020 (Tim LPPM, 
2020). Kegiatan pengabdian masyarakat Kegiatan pengabdian masyarakat ini menggunakan pendekatan PAR yang dilaksanakan secara kaloboratif dengan melibatkan majelis Ta'lim An-Nur yang ada di Desa Rompo Kecematan Langgudu Kabupaten Bima. Secara aplikatif KKN berbasis PAR (Participatory Action Research). Pada dasarnya PAR merupakan penelitian yang melibatkan semua pihak yang relevan dalam meneliti secara aktif bersama-sama tindakan saat ini terhada suatu masalah dalam rangka untuk mengubah dan memperbaikinya (Mansour, 2002). Pelaksanaan pengabdian masyarakat melalui kegiatan KKN-PAR didasari oleh pencapain kebutuhan dalam melakukan perubahan terhadap berbagai persolan dalam kehidupan sosial masyarakat (Tim LPM, 2008). Adapun bentuk pelaksanaan kegiatan pengabdian masyarakat ini dilakukan secara kaloboratif menenakan pada serangkaian kegiatan pembinaan bebasis komunitas pada aspek keagamaan kepada majelis Ta'lim An-Nur yang ada di Desa Rompo Kecematan Langgudu Kabupaten Bima.

\section{HASIL DAN PEMBAHASAN}

\section{Kondisi Maelis Ta'lim An-Nur Sebagai Subjek Dampingan Di Desa Rompo Kecamatan Langgudu Kabupaten Bima}

Mejelis ta'lim yang ada di desa rompo sebelumnya telah terbentuk dan berjalan, namun karna sekarang sedang pada masa Pandemi Covid-19 majlis taklim sudah tidak berjalan lagi sepeti biasanya atau di berhentikan sebagaimana dalam prtokol kesehatan bahwa tidak diperbolehkan untuk mengumpulkan khalayak banyak. Selain itu masyarakat yang ada di desa rompo masih minim akan ilmu pengetahuan keagamaannya. Sehingga dengan hadirnya KKN-PAR Desa Rompo ingin mengaktifkan kembali dan mengembangkan Majlis Taklim yang ada di Desa Rompo sebagai sarana pendidikan masyarakat khususnya di Bidang Keagamaan. Kegiatan Majlis taklim ini dilaksankan di setiap mushola dan mesjid yang ada di tiap-tiap dusun yang dilakukan secara bergilir. Waktu pelaksanaannya satu kali dalam seminggu stiap hari jum'at. Adapun tujuan mengaktifan kembali majlis di Desa rompo yaitu sebagai wadah persatuan dan kekeluargaan yang diharapkan mampu mempererat tali silarrahmi diantara ibu-ibu sesama jemaah juga dengan sesama muslimah yang ada di Desa Rompo, menumbuhkan rasa cinta yang mendalam kepada sang pencipta melalui dzikir yang lantunkan juga membina akhlak yang baik sebagaimana yang sudah di contohkan dalam Al-Qur'an dan Hadist Nabi Muhammad SAW.

\section{Pemetaan Masalah Ta'lim An-Nur Sebagai Subjek Dampingan Di Desa Rompo Kabupaten Bima}

Majelis tak'lim sebagai lembaga lembaga pendidikan non formal berkembang pesat di indonesia. Baik di kota-kota besar maupun di desa pasti terdapat mejelis taklim yang kebanyakan didominasi oleh kaum perempuan terutama kaum ibu. Lembaga pendidikan non formal termasuk kategori lembaga pendikan yang teratur namun tidak mengikuti peraturan-peraturan yang tepat dan kuat. Sebagai lembaga pendidikan non formal, majlis taklim mejamur di Indonesia dengan identitasnya masing-masing, salah satunya dengan seragam. Belakangan ini kita bisa melihat banyak ibu-ibu yang mengikuti pengajian menggunakan seragam yang sama dan menunjukan ciri khas majlis taklimnya masingmasing. Majelis taklim bukan hanya bergerak dalm bidang keagamaan saja melainkan juga 
dibidang sosial dan budaya. Dalam bidang keagamaan biasnaya meliputi pengajian, membaca al-qur'an, dan hal-hal yang berkaitan dengan ibadah. Dalam bidang sosial budaya, majlis taklim berusaha untuk meluruskan adat atau budaya yang melenceng dari ajaran islam yang berkembang di masyarakat.

Belakangan ini anyak maslah yang terjadi dalam kehidupan masyarakat diantaranya penyimpangan aqidah, perbedaan cara beribadah, gosip antar tetangga, perekonomian lemah, pamer harta antar tetangga, dan masih banyak lagi masaalah lain tentang kehidupan keagamaan di masyarakat. Dalam kehidupan bermasyarakat tentu banyak perbedaan cara beribadah satu sama lain. Hal itu terjadi karena adanya perbedaan mazhab yang dianut oleh seseorang. Massalah lain yang terjadi di kehidupan masyarakat yaitu mengenai ekonomi. Lemahnya perekonomian di masyarakat bisa menimbulkan kesenjangan antara si kaya dan si miskin. Selain itu, di kehidupan masyarakat biasanya terjadi saling pamer harta antar tetangga yang satu dengan yang lain sehingga menimbulakan sifat hasad atau dengki. Dengki adalah sifat yang dimiliki seseorang yang menginginkan hilangnya kesenangan yang dimiliki oleh orang lain dan berusaha memindahkannya kepada dirinya. Sifat hasad itu adalah sifat yang jelek dan sebenarnya menyakiti dan menyiksa pemiliknya sebelum ia menyakiti orang lain.

Beberapa masalah kehidupan masyarakat di atas menunjukan majlis taklim sangat diperlukan keberadaannya untuk mennagani masalah-masalah tersebut. Majlis taklim sebagai lembaga non formal di masyarakat merupakan sarana yang sangat petensial untuk menyampaikan dakwah islam dan membina masyarakat. Agar majlis ta'lim dapat menjadi wadah pembinaan umat menuju masyarakat Islam, majlis taklim tidak boleh dijalankan sebagai sebuah aktivitas rutin belajar mengajar tanpa arah dan tujuan yang jelas. Seharusnya majlis taklim bertujuan: 1) Mengokohkan aqidah (keiman) pesertanya, 2) Menjadikan pesertanya menjadi sebagi pribadi yang selalu terikat dengan syari'at islam dalam kehidupan seharinya, 3) Menjadikan pesertanya menjadi ibu yang mendidik anaknya dengan baik, sehingga menjadi kader umat yang berkualitas, 4) Menjadikan pesertanya sebagai pejuang penegakkan syari'at dalam masyarakat. Karena tujuan inilah kehadiaran pengajian majlis taklim dipandang cukup memberi arti penting bagi penyebaran dan pembinaan ajaran islam di kalngan masyarakat. Sebab, sekalipun keberadaannya terbatas pada kelompo-kelompok kecil, namun kegiatannya langsumng menyentuh masyarakat yang membutuhkan pembinaan agama Islam.

\section{Strategi Pelaksanaa Program Penguatan Peran Dakwah Majelis Ta'lim An-Nur Desa Rompo Kecematan Langgudu Kabupaten Bima}

Pelaksanaan.yaitu seluruh proses pemberian motivasi kerja kepada para bawahan sedemikian rupa sehingga mereka mampu bekerja dengan ikhlas demi tercapainya tujuan organisasi dengan efisien dan ekonomis. Bagi pelaksanaan kegiatan dakwah, penggerakan merupakan fungsi yang sangat penting diantara fungsi manajemen lainnya. Karena berhadapan dengan pelaksanaan kegiatan dakwah. berdasarkan fusngi dakwah di atas maka langkah-langkah dari penggerakan seperti; kegiatan pembimbingan, penjalinan hubungan, penyelenggaraan komunikasi dan pengembangan atau peningkatan pelaksana kegiatan pembinaan. Fungsi penggerakan dalam pelaksanaan pengajian Amanah dilakuk an oleh sang ketua (pemimpin). Seorang ketua dituntut untuk bekerja sama dengan seluruh anggotanya untuk mencapai kerja sama dengan anggotanya untuk mencapai jalan 
atau alternatif pemecahan apabila ada masalah yang tak terduga dalam pelaksanaan hingga kegiatannya terganggu. Seorang pemimpin juga harus memberikan motivasi atau dukungan kepada anggotanya supaya tetap semangat dalam menjalankan tugas masingmasing. Strategi pelaksanaan program yang digunakan pada pengajian majelis taklim Bunga Karang Desa Rompo adalah menggunakan dua metode yaitu:

1) Metode Mauidzoh Khasanah yaitu metode ceramah dengan lemah lembut yang berisi saling nasehat menasehati supaya dapat diterima dengan lapang dihati setiap jamaah.

2) Metode bil hikmah yang menitikberatkan pada ajakan kepada seluruh jamaah untuk berdzikir Bersama berupa dzikir Asmaul Husna dan dzikir-dzikir yang lain yang terdapat dalam tahlil. Ceramah merupakan salah satu thoriqoh dakwah yang paling tua yang pernah digunakan dalam sejarah dakwah. Namun sampai saat ini thoriqoh ini masih tetap digunakan dalam berbagai proses dakwah yang berlangsung baik dalam lingkungan formal maupun lingkungan nonformal. Thoriqoh ini dianggap yang paling murah dan sederhana, namun demikian dari segi pemberdayaan masih cukup potensial dalam rangka meningkatkan pengetahuan dan kemampuan daya piker dan usahausaha yang menyangkut perubahan sikap dan tingkah laku manusia. Di majelis taklim Bunga Karang Desa Rompo ceramah seringkali di sampaikan oleh ketua pengajian dengan tema kehidupan sehari-hari, misalnya tentang kematian dan di beri contoh real sehingga lebih mudah dipahami dan di cerna.

\section{Pelaksanaan Kegiatan Penguatan Peran Dakwah Majelis Ta'lim An-Nur Desa Rompo Kecematan Langgudu Kabupaten Bima}

Berdasarkan hasil kesepakatan bahawa majlis taklim Bunga Karang tealah dijadwalkan waktu pelaksanaanya yaitu:

1) Waktu pelaksanaan 1 kali seminggu pada setiap hari Jum,at pukul 16.00

2) Minggu I Tanggal 08 Agustus 2020 dengan tema Konsep Mendidik Anak dalam Pandangan Islam, Tempat Masjid Baitul Rahman. Pemateri Asni S.Pd.I;

3) Minggu II Tanggal 14 Agustus 2020 dengan tema Pentingnya Menjaga Tauhid dan Menjauhkan Diri dan Keluarga dari Segala Bentuk Kesyirikan. Tempat Mushola Arrahman. Pemateri Irwan M.Pd.I;

4) Minggu III Tanggal 21 Agustus 2020 dengan tema Mendidik Anak

5) Berdasarkan Pendidikan Lukmanul Hakim dan Wanita sebagai Pendidik yang Utama, Tempat Musholah Al - Latif, Pemateri Marhana

6) Minggu IV Tanggal 28 Agustus 2020 dengan tema Pentingnya Menjaga Sholat 5 Waktu, Tempat Mushola Al - Muslimin, Pemateri Ust. Mustamin Husen.

7) Minggu V Tanggal 4 September 2020 dengan Tema Hukum Riba dalam Pandangan Islam, Tempat Mesjid Baitul Rahman, Pemateri Marhana S.Pd.I.
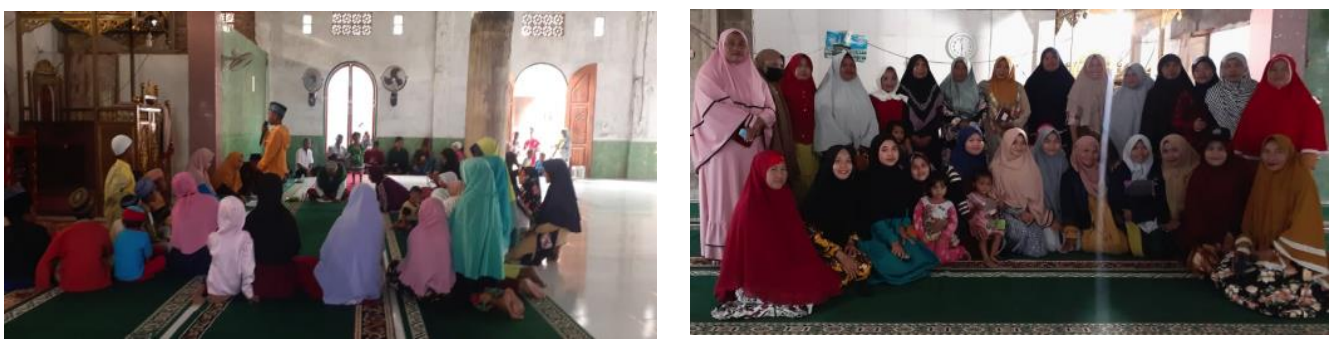

Gambar 1. Kegiatan Pembinaan Majelis Ta'lim An-Nur Desa Rompo 


\section{Evaluasi (Follow Up) Kegiatan Penguatan Peran Dakwah Majelis Ta'lim An-Nur Desa Rompo Kecematan Langgudu Kabupaten Bima}

Waktu yang sangat singkat tidak memungkinkan untuk sempat mengevaluasi secara keseluruhan, masyarakat disibukkan dengan kegiatan rutinitas kesehariannya. Akan tetapi hal itu dapat dilihat pada saat acara perpisahan yang kami lakukan bersama masyarakat, dimana masyarakat antusias sekali untuk memeriahkan acara tersebut karena hasil pengabdian terhadap masyarakat ini sudah memberikan perubahan pola pikir masyarakat walaupun tidak secara keseluruhan. Beberapa tokoh masyarakat yang kami temukan hanya bisa mengkritik tanpa melahirkan solusi untuk menyelesaikan masalah dalam proses pelaksanaan program kerja dan kegiatan lainnya.

\section{SIMPULAN}

Sebagai sebuah lembaga pendidikan non formal yang memiliki ciri khas keagamaan yang diselenggarakan oleh masyarakat, majlis taklim memiliki peran yang sangat strategis dalam menjalankan salah satu fungsinya untuk mendidikan dan memberikan pelayanan kepada umat. Peran-peran strategis yang di maksud adalah peran majlis taklim sebagai lembaga pendidikan umat, lembaga peningkatan ekonomi umat serta lembaga kesehatan mental umat. Untu menjalankan peran tersebut, melihat kondisi rill di Desa Rompo saat ini Majlis Ta'lim An-Nur perlu mengadakan berbagai pembenahan sebagai upaya peningkatan. Pembenahan-pembenahan tersebut dapat dikonsentrasikan ke dalam empat bidang kurikulum, bidang sarana dan prasarana, bidang kelembagaan dan ketenagaan (SDM).

\section{UCAPAN TERIMA KASIH}

Disampaikan terima kasih kepada selauruh stakeholder yang telah mendukung terlaksana kegiatan pengabdian masyarakat ini mulai dari unsur pimpinan LPPM, Dekan Fakultas Tarbiyah, dan Ketua Prodi dilingkup IAI Muhammadiyah Bima. Terimah kasih secara khusus juga disampikan kepada paar ibu-ibu majelis ta'lim An-Nur Desa Romo Kecamatan Langgudu Kabupaten Bima yang telah berpartisipasi aktif dalam kegiatan pengabdian ini. Semoga kegiatan pengabdian ini mmeberikan dapat positi terhadap konsep pengembanagn kegiatan dakwah bagi majelis ta'lim An-Nur Desa Romo Kecamatan Langgudu Kabupaten Bima.

\section{DAFTAR PUSTAKA}

Arship. (2015). Data Pemetaan Wilayah Desa Rompo Kecematan Langgudu Kabupaten Bima. Desa Rompo.

Hidayah, N. (2017). Peran Majelis Ta'lim Dalam Meningkatkan. 97.

Ibnu Singorejo. (2020). Pengertian Majelis Taklim. https://pontren.com/2020/03/29/pengertian-majelis-taklim/

Mansour, F. (2002). Jalan Lain. Yogyakarta: Pusataka Pelajar.

Marzuki, A., \& PdI, M. (2016). Dinamika Dan Peran Majelis Ta'lim Dalam Meningkatkan Pengetahuan Keagamaan Di Wilayah Suku Tengger. 1, 14.

Tim Kkn-Par. (2020). Hasil Obseravsi Dan pemataan Masalah Program KKN-PAR Di Desa Rompo Kabupaten Bima. 
Tim LPM. (2008). Modul Pelatihan Kuliah Kerja Nyata (KKN) Transformatif IAIN Sunan Ampel Surabaya. Suarabaya: LPM IAIN Sunan Ampel.

Tim LPPM. (2020). Buku Pedoman KKN-PAR LPPM IAI Muhammadiyah Bima. Kota Bima: LPPM IAIM Bima. 